\title{
Rauwolfia vomitoria Root Bark Extract Affects the Cervical Ventral Horn Cells of the Spinal Cord
}

\author{
Moses Bassey Ekong*, Ngozi Jane Muonagolu, Utibeabasi Bassey Akpan \\ Department of Anatomy, University of Uyo, Uyo, Nigeria
}

\begin{abstract}
Background: Rauwolfia vomitoria is a tropical shrub of Apocynaceae family, and a widely used nutraceutical containing bioactive alkaloids such as reserpine and yohimbine with reported antipsychotic, sedative and Parkinson-like effects. The pathway by which these become evident is through the spinal cord, a major reflex centre and conduction pathway of the brain and the rest of the body. This study therefore investigated the role of R. vomitoria on the microstructure of the cervical ventral horn cells of Wistar rats.

Methods: Twenty-four adult male Wistar rats with average weight $221 \mathrm{~g}$ were divided into four groups ( $\mathrm{n}=6$ ); control, $200 \mathrm{mg} / \mathrm{kg}$, $300 \mathrm{mg} /$ $\mathrm{kg}$ and $400 \mathrm{mg} / \mathrm{kg}$ body weight of R. vomitoria root bark extract administered orally for seven days. On the eight day, the animals were anaesthetized with ketamine hydrochloride $(10 \mathrm{mg} / \mathrm{kg}$; i.p); and perfusion-fixed sacrificed. The cervical vertebrae were exposed and crackedopen and the spinal segment C3-C5 were excised and post-fixed in $10 \%$ buffered formalin for 48 hours. The tissues were then routinely processed for histological study using haematoxylin and eosin staining method.

Results: The results showed general weakness, dull and drowsy behaviour, with hypertrophy of the ventral horn neurons in the $200 \mathrm{mg} / \mathrm{kg}$, $300 \mathrm{mg} / \mathrm{kg}$ and $400 \mathrm{mg} / \mathrm{kg} \mathrm{R}$. vomitoria groups. There was hyperplasia $300 \mathrm{mg} / \mathrm{kg}$ and karyorrhectic appearance of some of the ventral horn neurons with no difference $(\mathrm{p}>0.05)$ in the spinal cervical ventral horn cell population between the test groups and the control.
\end{abstract}

Conclusion: R. vomitoria caused some behavioural changes and alterations in the cellular integrity of the C3-C5 spinal ventral horn neurons.

Keywords: Rauwolfia Vomitoria; Spinal Cord; Neurons; Glial Cells; Wistar Rats

\section{Introduction}

Over the years, nutraceutical extracts have been reported to contain therapeutic agents, and have been extensively explored for their potentials in the treatment of a wide range of health conditions.[1] One of such herbs widely used for its antipsychotic effects is Rauwolfia vomitoria. [2] This herb also known either as African serpent wood, African-snake root or swizzle stick is also known in local Nigerian languages; asofeyeje in Yoruba, ira in Igbo, wadda in Hausa, and mmoneba or utoenyin in Efik and Ibibio languages, respectively.[3] $R$. vomitoria extracts are rich in $\beta$-carboline and indole alkaloids, many of which are contained in its stem, leaf and root. R. vomitoria is also rich in saponins and flavinoids.[4,5] Of the several alkaloid constituents, reserpine and yohimbine are the best known in terms of mechanism of action.[6-8] The $R$. vomitoria is an antihypertensive and sedative agent, $[3,9,10]$ and is used for the treatment of hypertension, schizophrenia, paranoia and cancer.[2,11,12] It acts as an antidepressant in low doses, while high doses cause monoamine depletion and depression.[13] Other uses of this plant include treatment of a variety of ailments such as fever, general weakness, gastrointestinal diseases, liver diseases, psychosis, pain and cancers. [14,15] However, despite these various health benefits, some side effects such as drowsiness, nasal congestion, paradoxical anxiety, depression and Parkinson-like symptoms have been reported. $[6,12,16]$ Histological alteration in different brain areas have been reported,[3,17-22] Also, overdose may cause respiratory depression, slowed heartbeat, hypotension, confusion, tremors, convulsions and gastro-intestinal distress.[16] One pathway by which these tremors and convulsion become evident is through the spinal cord. $[23,24]$

The spinal cord is a major reflex centre and conduction pathway of the body and the brain, and also forms a direct pathway by which motor function is influenced.[25,26] Sedation is reported as one of the actions of $R$. vomitoria on the nervous system, and how this may influence the spinal cord is not known. The reported plethora of side-effects and the likely effect on the motor neurons of spinal cord necessitated this study of $R$. vomitoria root bark extract on the ventral horn cells of the cervical spinal segment of Wistar rats.

\section{Materials and Methods:}

Twenty-four (24) adult albino Wistar rats of average weight $221 \mathrm{~g}$ were used for this study. Ethical approval was obtained from the Faculty of Basic Medical Sciences 
Ethical Committee, and the experiment was carried out at the Animal House Facility of the Faculty of Basic Medical Sciences of University of Uyo, Nigeria. The animals were allowed free access to rat chow (Vital Feed Company Limited, Nigeria) and clean water ad libitum.

Preparation of $\boldsymbol{R}$. vomitoria Roots: Roots of $R$. vomitoria were identified and harvested in a local farm at Ekpene Obo in Esit-Eket Local Government Area of Akwa-Ibom State, Nigeria. The roots were washed and the bark was separated from the cambium, air-dried for one week and then pulverized into powder using kitchen blender. The $R$. vomitoria root bark powder was extracted using $80 \%$ ethanol. Dry extracts were obtained using a rotary evaporator and Plus 11 Gallenkamp oven at $45-50{ }^{\circ} \mathrm{C}$ and stored in a refrigerator at $4{ }^{\circ} \mathrm{C}$ until use.

Experimental protocol: Two grams of the $R$. vomitoria root bark extract was dissolved in $30 \mathrm{ml}$ of distilled water and the actual dosages were calculated based on the body weights of each rat. The animals were divided into four groups ( $\mathrm{n}=6)$ of control, $200 \mathrm{mg}, 300 \mathrm{mg}$ and $400 \mathrm{mg}$ of $R$. vomitoria per kilogram body weight ( $\mathrm{kg} \mathrm{b.w.),} \mathrm{which} \mathrm{also}$ served as the dosage regimens. The control group received $2 \mathrm{ml} / \mathrm{kg}$ of distilled water, and all administrations were done orally for seven days. The animals were monitored for behavioural changes throughout the duration of the experiment. On day 8, the animals were anaesthetized with ketamine hydrochloride (Rotex Medical, Germany; 50 $\mathrm{mg} / \mathrm{kg}$, i.p) and sacrificed. The thorax of the animals was dissected and transcardially perfused with $1 \mathrm{M}$ phosphate buffered saline followed by $10 \%$ buffered formalin. The cervical vertebrae were exposed and cracked open, and the spinal segment $\mathrm{C} 3-\mathrm{C} 5$ were excised and postfixed in $10 \%$ buffered formalin for 48 hours. The tissues were then routinely processed for histomorphology with haematoxylin and eosin stains (H\&E) through paraffinized 10 micrometre thin sections. The sections were quantified by means of ImageJ ${ }^{\circledR}$ software (version $1.37 \mathrm{c}$ ). Briefly, images of the whole dentate gyrus was obtained for each section and randomly mapped with the Image $\mathrm{J}$ gridlines. Counting of cell nuclei was done manually taking into consideration the nuclei on the upper and right borders of the mapped areas. Data were analyzed using one way analysis of variance by means of Graphpad prism (version 5) and post-hoc Tukey test used to compare group difference. Statistically significance was determined at probability level $p \leq 0.05$, and data represented as mean \pm standard error of mean.

\section{Results}

Behavioural appraisal: At the beginning of the experiments, all the animals were apparently healthy and agile, with solid faecal boli. However, in the course of the experiment all the animals administered doses of $R$. vomitoria appeared generally weak, dull and drowsy compared with the control group. The faecal boli appeared semi solid, while there was also decreased food and water intake in these test groups.

Histological Observations :The ventral horn of the control group showed distinctive appearance of meshwork of cell neurons and glial processes. Glial cells appeared more numerous than neurons, with no obvious histopathology observed (Figure 1 and 2a). The ventral horn of the $200 \mathrm{mg} /$ $\mathrm{kg} R$. vomitoria group showed slight hypertrophy especially of the neurons. The glial cells also appear less distinct compared with the control (Figure 2b). The ventral horn of the $300 \mathrm{mg} / \mathrm{kg} R$. vomitoria group showed hypertrophy especially of the neurons and hyperplasia of the glia cells with pyknotic appearance of the nuclei (Figure 2c). The ventral horn of the $400 \mathrm{mg} / \mathrm{kg} \mathrm{R}$. vomitoria group showed hypertrophy of cell neurons with karyorrhectic appearance of some of the nuclei (Figure 2d). There was no difference $(p>0.05)$ in cell population between the test groups and the control. Also, there was no difference $(p>0.05)$ in cell population among the test groups (Figure 3).

\section{Discussion}

This study investigated the effect of $R$. vomitoria on the ventral horn cells of the spinal cervical segment of Wistar rats. The groups administered different doses of $R$. vomitoria showed general weakness, dull and drowsy behaviour, and body weights loss. These behavioural and morphological changes are the visible signs of $R$. vomitoria toxicity as previously reported.[3,17-22].Histologically, there was slight hypertrophy of the neurons with less distinct glial cells in the spinal cervical ventral horn, and no difference

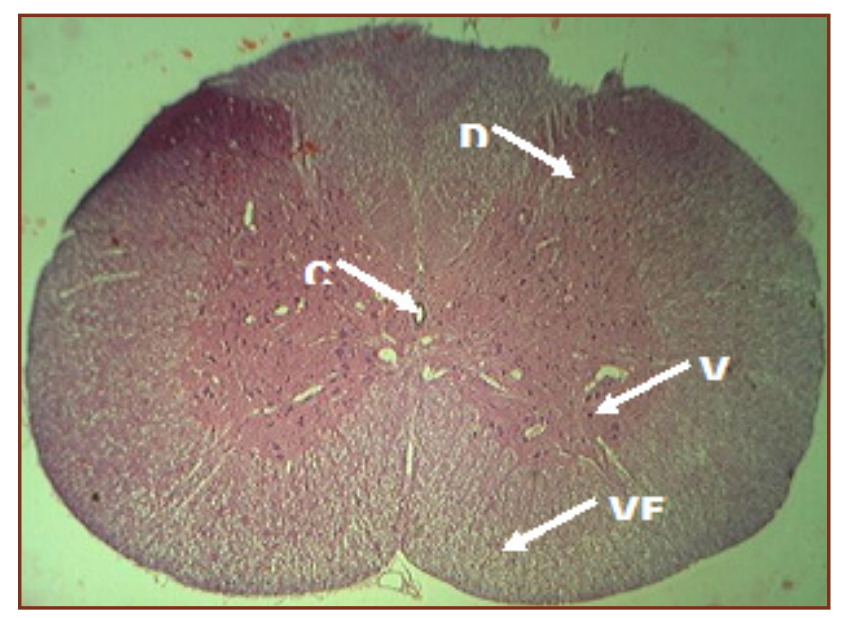

Fig. 1: Photomicrograph of the section of the spinal cord segment C3-C5. Central canal (CC); Dorsal horn (DH), Ventral horn (MH); Ventral Funiculus (VF); H\&E, ×40. 


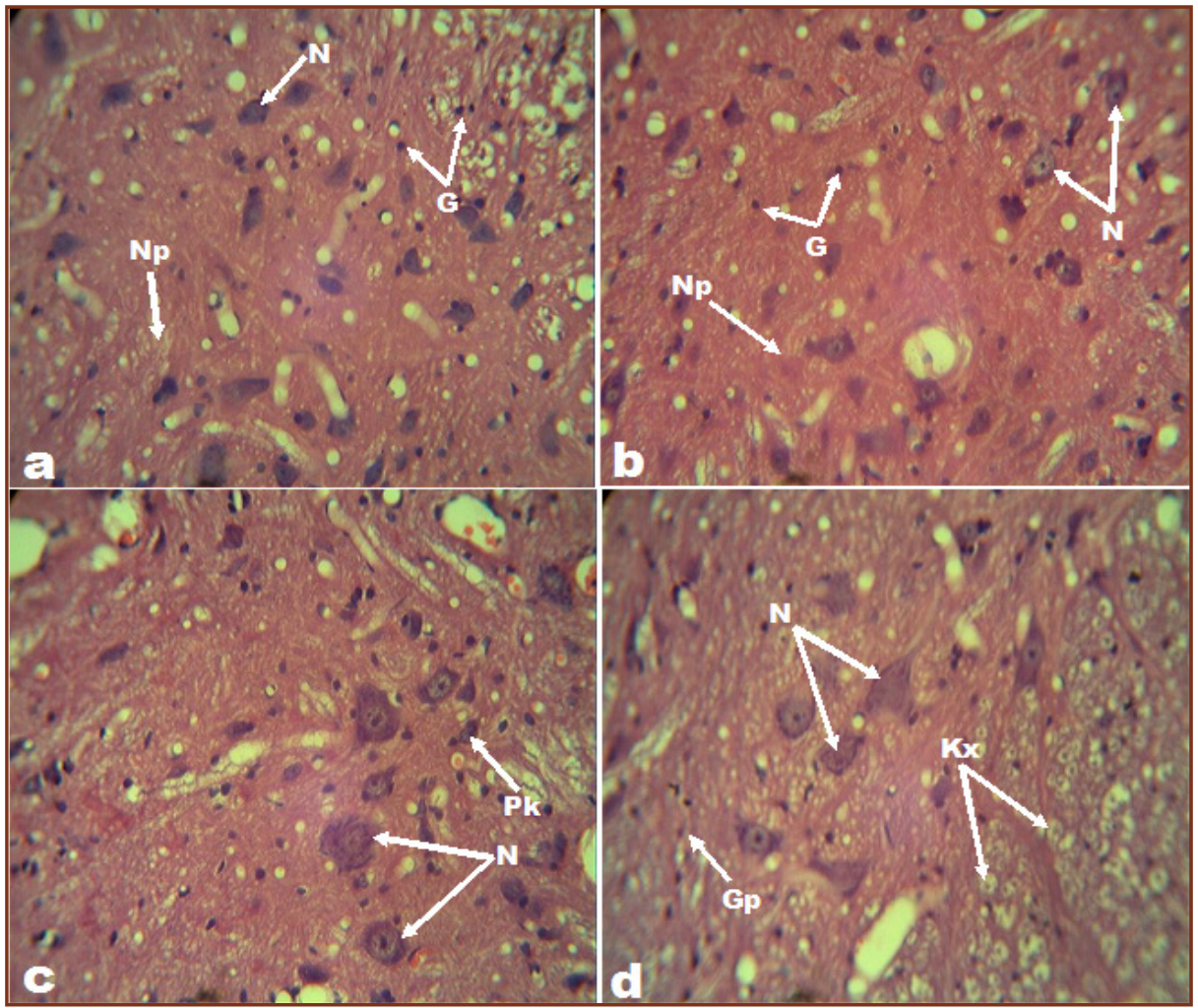

Figure 2: Photomicrographs of Sections of the Ventral Horn of Spinal Segment C3-C5 a. The ventral horn of control group shows distinctive appearance of meshwork of neurons and their processes, as well as glial; $b$. The ventral horn of the 200 $\mathrm{mg} / \mathrm{kg} \mathrm{R}$. vomitoria group shows slight hypertrophy of neurons and less distinct glial cells; $\mathrm{c}$. The ventral horn of the $300 \mathrm{mg} /$ kg R. vomitoria group shows hypertrophy and hyperplasia of cell neurons with pyknotic (Pk) appearance of some nuclei; d. The ventral horn of the $400 \mathrm{mg} / \mathrm{kg} \mathrm{RV}$ group shows hypertrophy of neurons with karyorrhectic (Kx) appearance of some of the nuclei. Neurons (N); neuronal processes (Np); glial cells (G); H\&E, $\times 400$

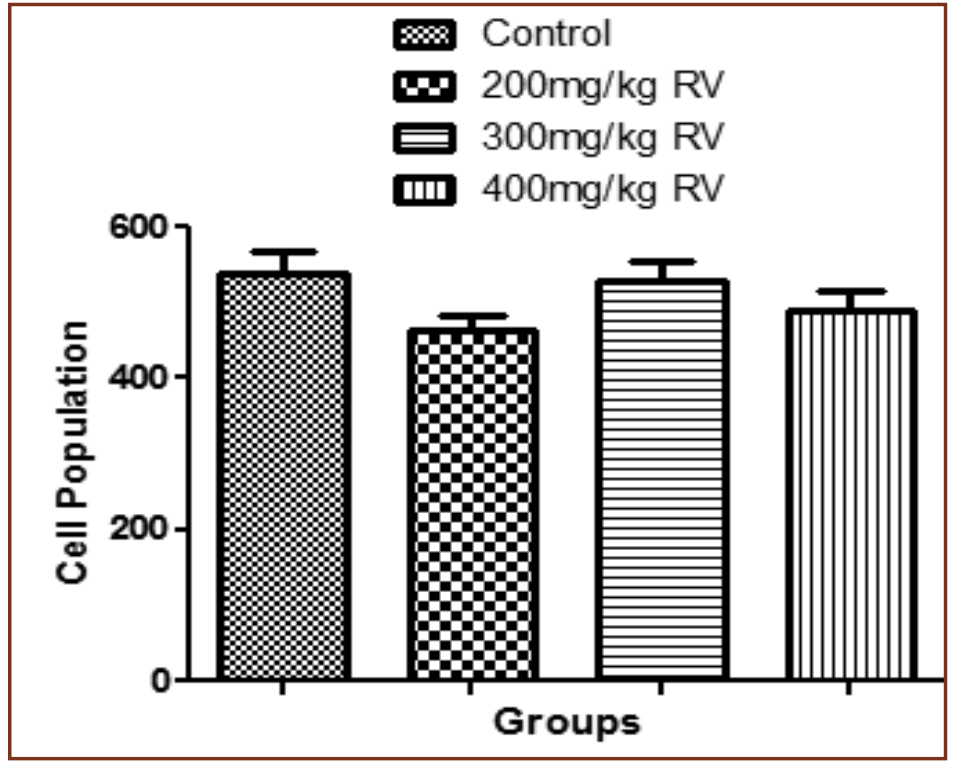

Figure 3: Ventral Horn Cell Population of the Spinal Cord Segment C3-C5 Data presented as Mean \pm Standard Error of Mean; Data is not significantly different from the control at $\mathrm{p} \leq \mathbf{0 . 0 5} \mathrm{p}=\mathbf{0 . 1 4 1 9}$; F-ratio $=2.031 \mathrm{RV}=\mathrm{Rauwolfia}$ vomitoria 
( $\mathrm{p}>0.05$ ) in cell population in the $200 \mathrm{mg} / \mathrm{kg}$ R. vomitoria group compared with the control. Hypertrophy, which is the enlargement of cells and its organelles usually arise as compensation reaction to trauma of the tissue.[27] $R$. vomitoria have been reported to cause such trauma in different body tissues, [3,17-22] indicating that it may also affect spinal cervical ventral horn cells as in the present study. The non-prominent glia cells may be due to cell division changes, which may have inhibited their staining ability. This is because $R$. vomitoria stimulates gliosis. [10,17-22]

In the $300 \mathrm{mg} / \mathrm{kg} R$. vomitoria group, there was hypertrophy of the neurons and hyperplasia of the glia cells with pyknotic appearance of some of the nuclei in the spinal cervical ventral horn, and no difference $(\mathrm{p}>$ 0.05 ) in cell population compared with the control. This result is similar to that of the $200 \mathrm{mg} / \mathrm{kg} R$. vomitoria group and more probably due to the higher dosage. This result is similar to that of the $200 \mathrm{mg} / \mathrm{kg} \mathrm{R}$. vomitoria group and more probably due to the higher dosage. These additional features signify changes due to trauma which has progressed to the early cell death process. This is because pyknosis signify an irreversible condensation of chromatin in the nucleus of a necrotic cell.[28]

In the $400 \mathrm{mg} / \mathrm{kg} R$. vomitoria group, there was hypertrophy of neurons with karyorrhectic appearance of some of the nuclei in the spinal cervical ventral horn cells, and no difference $(p>0.05)$ in cell population compared with the control. This result is similar to that of the 200 and $300 \mathrm{mg} /$ $\mathrm{kg} R$. vomitoria groups and more probably due to the higher dosage. These additional features signify changes which has progressed to the cell death process as karyorrhexis signifies an irreversible condensation of chromatin in the nucleus of a necrotic cell.[28]

The histopathological changes of the cervical ventral horn cells of the test groups could also be due to increased tissue demand, hormonal dysfunction, chronic inflammatory response or compensation for damage.[29].The This may hinder the role of these cells in supporting motor functions. $[30] R$. vomitoria has been reported to cause loss of cellular integrity of the cerebral cortex, cerebellum and olfactory bulb in animal models and, hypertrophy and hyperplasia of osteoblasts, which supports the present results. [3,10,1722,31]

\section{Conclusion}

$R$. vomitoria alter behavioural and cellular architecture of the spinal ventral horn $\mathrm{C} 3-\mathrm{C} 5$ segments and these changes were dose dependent.

\section{Acknowledgment}

We acknowledge with thanks Dr Monday Akpanabiatu who made available the roots of the $R$. vomitoria, and the Animal House Facility personnel who took care of the animals.

\section{References}

1. Valnet J. The practice of aromatherapy: A classic compendium of plant medicines and their healing properties. Original ed. Rochester, NY: Healing Arts Press. 1982.

2. Obembe A, Sokombab EN, Sijuwolaa OA, et al. Antipsychotic effects and tolerance of crude Rauvolfia vomitoria in Nigerian psychiatric inpatients. Phytother Res 1994;8:218-223.

3. Eluwa MA, Idumesaro NB, Ekong MB, Akpantah AO, Ekanem TB. Effects of aqueous extract of Rauwolfia vomitoria root bark on the cytoarchitecture of the cerebellum and neurobehaviour of adult male Wistar rats. IJAM 2008; 6(2):3081.

4. Bemis DL, Capodice JL, Gorroochurn P, Katz AE, Buttyan R. Anti-prostate cancer activity of a $\beta$-carboline alkaloid enriched extract from Rauwolfia vomitoria. International $\mathrm{J}$ Oncol 2006;29:1065.

5. Duez $\mathrm{P}$, Chamart S, Vanhaelen M, Vanhaelen-Fastré R, Hanocq M, Molle L. Comparison between high-performance thin-layer chromatography-densitometry and highperformance liquid chromatography for the determination of ajmaline, reserpine and rescinnamine in Rauwolfia vomitoria root bark. J Chromatography A 1986;356:334.

6. Barcelos RCS, Benvegnü DM, Boufleur N, et al. Short term dietary fish oil supplementation improves motor deficiencies related to reserpine-induced parkinsonism in rats. Lipids 2010;46(2):143-149

7. Henry J, Scherman D. Radioligands of the vesicular monoamine transporter and their use as markers of monoamine storage vesicles. Biochem Pharmacol 1989;38(15):2395-2404.

8. Hai-Bo L, Yong P, Lu-qi H, Jun X, Pei-Gen X. Mechanism of selective inhibition of yohimbine and its derivatives in adrenoceptor $\alpha 2$ subtypes. J Chem 2013;(2013):783058

9. Oyedeji L (2007). Drugless Healing Secret. 3rd ed. Ibadan: Panse Press Ltd.

10. Ekong MB, Peter AI, Ekpene UU, et al. Gongronema latifolium modulates Rauwolfia vomitoria induced behavior, biochemicals, and histomorphology of the cerebral cortex. Int J Morphol 2015;33:77.

11. Shamon SD, Perez MI. Blood pressure lowering efficacy of reserpine for primary hypertension. Cochrane Database Syst Rev 2009; CD007655.

12. Leão AHFF, Aldair JS, José RS. Molecular, neurochemical, and behavioral hallmarks of reserpine as a model for parkinson's disease, new perspectives to a long-standing model. Brain Pathol 2015;25:377-390. 
13. Lopez-Munoz F, Bhatara VS, Alamo C, Cuenca E. Historical approach to reserpine discovery and its introduction in psychiatry. Actas Esp Psiquiatr 2004;32(6):387-395.

14. Bisong SA, Brown R, Osim EE. Comparative effects of Rauwolfia vomitoria and chlorpromazine on locomotor behaviour and anxiety in mice. $\mathrm{J}$ Ethnopharmacol 2010;132:334-339.

15. Campbell-Tofte JI, Molgaard P, Josefsen K. Randomized and double-blinded pilot clinical study of the safety and anti-diabetic efficacy of the Rauvolfia-Citrus tea, as used in Nigerian traditional medicine. J Ethnopharmacol 2011;133:402-411

16. Okpako DT (1991). Principles of Pharmacology: A Tropical Approach. Cambridge University Press, New York.

17. Ekong MB, Ekpene UU, Nwakanma AA, Peter AI, Etuknwa BT. Rauvolfia vomitoria and Gongronema latifolium stimulate cortical cell proliferations. Ann Bioanthropol 2016;4:41-46.

18. Ekong MB, Ekpene UU, Thompson FE, Peter AI, Udoh NB, Ekandem GJ. Effects of co-treatment of Rauwolfia vomitoria and Gongronema latifolium on neurobehaviour and the neurohistology of the cerebral cortex in mice. Internet J Med Update 2015;10(1):3-10.

19. Ekong MB, Peter AI, Edagha IA, Ekpene UU, Friday DA. Rauwolfia vomitoria inhibits olfaction and modifies olfactory bulb cells. Brain Res Bullet 2016;124:206.

20. Ekong MB, Ekpene UU, Nwakanma AA, Bello EF. The combination of the extracts of rauwolfia vomitoria and gongronema latifolium show protective effects on the cerebellum. Synergy 2017;5:29-34.
21. Ekong MB, Nwakanma AA. Rauwolfia vomitoria and gongronema latifolium extracts influences cerebellar cortex. ADCN 2017;1(3):1-6.

22. Ekong MB, Peter AI. Co-treatment of rauwolfia vomitoria and gongronema latifolium affects cerebellar cell population in mice. J Animal Husbandry Dairy Sci 2017;1(1):1-7.

23. Meythaler JM, Tuel SM, Cross LL. Spinal cord seizures: a possible cause of isolated myoclonicactivity in traumatic spinal cord injury: case report. Paraplegia 1991;29:557-560.

24. Hashimoto T, Sato H, Shindo M, Hayashi R, Ikeda S. Peripheral mechanisms in tremor after traumatic neck injury. J Neurol Neurosurg Psychiatry 2002;73(5):585-587.

25. Rothwell J. Reflex pathways in the spinal cord. In: Control of Human Voluntary Movement. Springer, Dordrecht. 1994

26. West KB, Applegate E. Today's Medical Assistant: Clinical and Administrative Procedures. 3rd ed. Elsevier Health Sciences. 2015

27. Kusumoto FM. Cardiovascular Pathophysiology, Hayes Barton Press. 2004

28. Kroemer G, Galluzzi L, Vandenabeele P. Classification of cell death: recommendations of the nomenclature committee on cell death. Cell Death Differ 2009;16(1):3-11.

29. Porth C. Essentials of Pathophysiology: Concepts of Altered Health States. Lippincott Williams \& Wilkins. 2011

30. Kaminsky N, Bihari O, Kanner S, Barzilai A. Connecting malfunctioning glial cells and brain degenerative disorders. Genomics Proteomics Bioinform 2016;14(3):155-165.

31. Eluwa MA, Ekanem TB, Udoh PB, et al.. Teratogenic effects of crude ethanolic root bark and leaf extracts of rauwolfia vomitoria (apocynaceae) on the femur of albino wistar rat fetuses. J Histol 2013;(2013):363857. 